\title{
China in the Face of Economic Crisis
}

Valérie Niquet

\section{OpenEdition}

Journals

Édition électronique

URL : http://journals.openedition.org/chinaperspectives/4854

DOI : 10.4000/chinaperspectives.4854

ISSN : 1996-4617

\section{Éditeur}

Centre d'étude français sur la Chine contemporaine

\section{Édition imprimée}

Date de publication : 1 septembre 2009

ISSN : 2070-3449

\section{Référence électronique}

Valérie Niquet, "China in the Face of Economic Crisis », China Perspectives [En ligne], 2009/3 | 2009, mis en ligne le 01 septembre 2012, consulté le 28 octobre 2019. URL : http://journals.openedition.org/ chinaperspectives/4854; DOI : 10.4000/chinaperspectives.4854

(C) All rights reserved 
U

\title{
China in the Face of
}

\section{Economic Crisis}

\author{
VALÉRIE NIQUET
}

This article considers whether China can emerge from the global economic crisis with its current policies vindicated and its social order intact. Or will the Chinese development model fail to cope? Will the socio-economic situation and the ever-present, deeply held fear of turmoil force Beijing to resort to whipping up nationalism and adopting an aggressive economic and political stance abroad?

$\mathrm{S}$ ince early 2009, Beijing has made numerous statements and published reassuring figures to boost talk of a growth upturn round the corner. Despite such optimistic talk, the economic crisis gripping China and the rest of the world raises issues that have a bearing on the regime's own survival. While the Communist Party had hoped to demonstrate the wisdom of the path it chose in 1979 to both the developed world and to the former Soviet big brother, questions have arisen regarding the regime's ability to function efficiently in a time of stress.

It is 60 years since the Communists' victory in 1949 against the Kuomintang, which succumbed to its inability to pull China out of a deeply inegalitarian stagnation. While the conditions now are quite different, the Communist Party could well face accusations of having likewise failed to come up with the right remedies to the issues China has confronted for more than 150 years.

In fact the crisis has hit China hard, serving as a reminder that China remains a developing country buffeted by problems that had for long been masked by rapid growth. The economic decoupling theory that once held sway has lost its lustre, and the emphasis now is on realism and on finding solutions that can restore to the regime the only real basis of its internal and external legitimacy: its capacity to ensure rapid growth backed by an extraordinary potential.

The crisis has already had social and political consequences in China, and increasingly looks like a glitch in the system that could derail and threaten a heretofore apparently irresistible model of development and expansion.

\section{A worrisome situation}

Although China was initially sheltered from the financial crisis, it was hit hard when exports fell slowly at first in late 2008 and rapidly in early 2009. From minus 2.2 percent in
November and then minus 2.8 percent in December, the downturn reached minus 14 percent in January, minus 26 percent in February, minus 17.1 percent in March, minus 22.6 percent in April and minus 26.4 percent in May. Consequently, the trade surplus had fallen by 33 percent in May compared to the previous year, in line with a trend that began earlier in the year. China's other growth engine, foreign direct investment, largely drawn from Taiwan, Hong Kong, South Korea, and Japan - or the Cayman Islands also registered a steep fall of more than 20 percent over the same period the previous year and the first quarter of 2009 , thus posing an even greater threat to China's production and success model, at least in the near term. ${ }^{(1)}$

In a concrete sign of the seizure affecting the economic machine, the index of production costs for manufactured goods fell by 7.2 percent in May, and energy production fell by 10.4 percent, again continuing a trend begun in late 2008. ${ }^{(2)}$ The crisis has affected China's most dynamic regions, where much of the "China workshop" is based. These are labourintensive manufacturing industries, 30 percent of the production of which is meant for export, the sector that has been hit the hardest. ${ }^{(3)}$

Textiles, which accounted for half of China's trade surplus, were especially affected, as were the toy and shoe industries. Concentration of production exacerbated the incidence of closures, often highly localised but with significant consequences in terms of jobs lost. ${ }^{(4)}$ In all, 670,000 firms have closed shop since 2008, 62,400 of them in Guangdong alone, according

1. The Cayman Islands tax haven is both the top source of and destination for China's investments.

2. Andy Xie, "Chinese Manufacturers on the Brink of Failure," www.caijing.com, 3 February 2009

3. Tao Wang, "Asian Economic Perspective," UBS Investment Research, 7 January 2009.

4. David Barboza, "Textile Capital of China is Hobbled by a Downturn Gone Global," New York Times, 28 February 2009. 

a major part of it is the money sent back by migrant workers. ${ }^{(10)}$ In 2007, the average annual rural income was put at 4,700 yuan, with non-farm work accounting for 40 percent. The more than 20 percent fall in migrants' incomes between June and December 2008 has thus affected total rural income. (II)

More than 95 percent of migrant workers have no more than secondary education and are mostly engaged in manufacturing for export and in construction, both sectors suffering due to the economic crisis. ${ }^{(12)}$

According to the National Bureau of Statistics, "peasant workers" numbered 225 million at the end of 2008, and 140 million of them, or 62 percent of the total, were employed in regions other than their own. ${ }^{(13)}$ With 26 million migrants estimated to be unemployed as of early 2009 , there are worrying social consequences. ${ }^{(14)}$

Beyond these figures, the crisis starkly revealed the dysfunction crippling China's growth, which lacks real development but has spawned new inequalities. These are regularly denounced but have been ignored thanks to the prolonged growth. In fact, while China has become the third economic power, overtaking Germany since 2007, its per capita income was only $\$ 3,180$ in 2008, placing it 104th in world rankings. ${ }^{(15)}$

More worrying than migrants, whose "patience" is often cited by Chinese experts to warn of the risk of social explosion, are students in whom parents have invested great hope and resources and who are also affected by the crisis. Of the 5 million who graduated in June 2008, as many as 1.6 million had found no jobs by year end. By June 2009, 6.1 million new graduates will have entered the job market. Reflecting the authorities' concern over the risks stemming from a mass of frustrated youth, Human Resources and Social Security Minister Yin Weimin told the NPC in March 2009 that in view of the serious jobs situation, priority would be accorded to employing graduates.

While the crisis persists, affecting the whole Chinese model, the middle class that has been the main beneficiary and bulwark of support for the regime has also been hit hard. Flagship firms employing the country's emerging white collar workers, such as Lenovo and China Eastern, have suffered. Urban unemployment, officially estimated at 4.2 percent and at 9.4 percent by CASS, is rising apace. ${ }^{(16)}$

\section{Between awareness and control}

There is thus real awareness of the crisis, despite official statements claiming that China has the ability to recover and that no major social problems loom. The leadership's aim is to reassure the population and the outside world in order to gain the confidence that is crucial to China's growth. At the NPC session, Premier Wen Jiabao reaffirmed that despite the IMF's pessimistic forecasts, the 2009 growth rate would be 8 percent. In April, he said the economy was doing better than expected as shown by the - relatively - good industrial production figures. ${ }^{(17)}$

At the same time, President Hu said for his part that the crisis was a real test of the authorities' ability to ensure good "governance." (18)

What is at stake is Chinese leaders' ability to prove their quasi-Confucian power to be "good leaders" as well as the efficiency of the system over which they preside. The leadership's legitimacy essentially rests on economic growth, which, despite being inequitable, has benefited all of China. It is thus essential for the Chinese authorities to maintain at least the appearance of success, in hopes that a global recovery will help China resume its rapid growth path in 2010, the sole short-term means of ensuring social harmony without upsetting the system's political bases.

But the crisis could also deepen the differences within the Chinese leadership, as it contains mutually contradictory interest groups, albeit linked by the common desire to survive. ${ }^{(19)}$

By revealing the dysfunction in the system and reducing hopes for social progress, the crisis has further undermined confidence in the political apparatus, more so at the local level, where corruption, according to Chinese leaders' own denunciation, is rampant. A 2005 opinion poll of 500 students in provincial-level Party schools showed that 62.3 percent of them had confidence in the central authorities, but the figure fell sharply to 30.3 percent for provincial officials, 14.9 percent for municipal officials, 8.9 percent for county

10. There are an estimated 120 to 130 million migrant workers out of a rural population said to total 800 million.

11. Andy Xie, "Hard Landing Versus Stimulus," www.caijing.com, 20 January 2009, and Wang Tao, Asian Economic Perspective, op. cit.

12. Thanks to the stimulus plan, the construction sector, which is prone to speculative investment, has enjoyed a rebound in the first quarter of 2009. In Shanghai, preparations for Expo 2010 have fuelled a building boom.

13. http://www.stats.gov.cn/tjfx/fxbg/t20090325_402547406.htm.

14. Peh Shinghuei, "China Signals Shift in Focus Eyes 8\% Growth," Straits Times, 6 March 2009, and Chen Xiwen, Central Committee Rural Work Leading Group, cited by Associated Press, 2 February 2009.

15. Liang Jing, "Zhongong de weiji yu zhongguo de shengji" (Risks for the Party and China's future), Xin shiji, 2 December 2008, and interview with Wu Jianmin, president of the China Foreign Affairs University, March 2009.

16. Edward Wong, "College Educated Students Feel Job Pinch," The New York Times, 24 January 2009.

17. "China Plans more Stimulus to Boost Consumption," Reuters, 12 April 2009.

18. Xinhua, 22 January 2009.

19. Minxin Pei, "Will the Chinese CCP Survive the Crisis," Foreign Affairs, 12 March 2009. 
(xian) level leaders, 5.6 percent for township (xiang) leaders, and 3.7 percent for officials in towns (zhen). As per Chinese figures, of the 4,000 "duties" collected in China, the majority are levied by local authorities and 2,000 of them are deemed illegal. ${ }^{(20)}$

This gathering debate is likely to spread from among the experts' circle to that of politicians and to touch on the need for and pace of political reform, although officially, statements categorically rejecting any "Western-style" reforms have proliferated.

On 10 December 2008, a manifesto entitled Charter 08 (Lingba xianzhang) began circulating on the Internet despite heavy censorship, calling for democratisation and the adoption of genuine rule of law. More worrying for the authorities who fear factionalism as a factor of vulnerability, the criticism and attacks came also from the Party's own albeit marginalised ranks, including people close to the deposed general secretary Zhao Ziyang, such as Hu Qili and Bao Tong. Debate choked off since the events of 1989 threatened to be reactivated, stoking the fears of "chaos" ever present in the collective subconscious of Chinese leaders - all the more so given that none of the current leaders have the charisma and, by some yardsticks, the legitimacy, of Mao Zedong or Deng Xiaoping.

According to some sources that are difficult to verify but whose information reflects openly voiced worries, President $\mathrm{Hu}$ presented a "secret report" to the third plenum of the 16th Party Central Committee in October 2008, denouncing the loss of idealism among the cadres, corruption and provincialism, lack of a sense of common good, weakness of domestic demand, unemployment, and public security tensions. ${ }^{(21)}$ Wu Jinglian, the former president of the State Council Development Research Centre, a leading light in China's economic reform and initiator of the socialist market economy concept, added his voice to the call for pursuing reform and modernisation in the political sphere, especially in the matter of the NPC's budgetary supervision. ${ }^{(22)}$

There is much criticism of an irrational budget allocation system, blamed in large part for the lack of development of the domestic market. In education, despite recent efforts to correct the trend, the budget share remains 2.2 percent, whereas in a comparable developing country such as India it is more than 4 percent. Similarly, more than 70 percent of rural residents have no access to even a minimal pension fund, and a mere 15 percent of the entire population enjoys some health insurance, the coverage of which is too limited for it to be really significant. ${ }^{(23)}$ Budgetary allocation for health accounts for barely 1 percent of GDP, according to
World Health Organisation figures (which rank China 156th among 196 countries), and drain away a high level of household savings.

Conversely, the allocation for administration, the Party's main support base consisting of officials and "cadres," takes up 25 percent of the budget. Public works, another source of influence-peddling, takes up more than 30 percent. ${ }^{(24)}$ The stimulus plan envisages strengthening social security, but Chinese experts point out that the part of the package earmarked for social security is extremely insufficient and could lead to an increase of no more than 0.3 percent of the share of the budget allocated to social security. ${ }^{(25)}$

Political reform, as well as the adoption of a social safety net, presents almost insurmountable challenges for a system whose limits have been exposed by the crisis that has now gripped China - the more so as doubts about the Chinese model and the slowdown in exports sparked by scandalous quality control failures had already begun rearing their heads in late 2007, the crisis having merely sped up the process. ${ }^{(26)}$

\section{A stimulus plan of dubious efficacy}

Noting the seriousness of the crisis, Beijing announced in 2008 a $\$ 586$ billion stimulus plan making up 6 percent of GDP and spread over two years. It has two aims: Domestically, in addition to inducing recovery, it seeks to correct weaknesses incurred from the crisis and attempts to achieve balanced growth. Externally it aims to show that China is a great power with the will and the means to act as meaningfully as other major international actors. The stimulus plan helped China take its place among the G20 Summit of major economies.

The plan envisages infrastructural development, recovery of the construction sector hit hard by the bursting of the economic bubble, strengthening the rural infrastructure, and a boost to social sector investments. It seeks to increase job-

20. Richard Baum, China Watcher: Confession of a Peking Tom, University of Washington Press, Washington, to be published in 2010, chapter 14. And Zhou Tianyong, SCMP.com, 6 December 2008.

21. In Zhengming, November 2008 , cited by Liang Jing, op. cit. These ideas have also been voiced by researchers in the sociology department of CASS, which annually publishes a "China Society Blue Book." See footnote 9.

22. Cary Huang, "Political Changes Must Come Next," SCMP.com, 3 December 2008.

23. Assistance is limited to 45 yuan annually, which in China today is highly insufficient. A gradual extension of the system to the whole population, announced in the autumn of 2008 , is limited to urban areas for now.

24. Zhou Tianyong, SCMP.com, 6 December 2008.

25. Wang Tao, "How Large Is the Stimulus Really?", www.caijing.com, 10 March 2009.

26. David Kelly, "China Facing the Inevitable," www.stratfor.com, 25 July 2008. 
creating projects and help create a "domestic market" to replace the external markets severely hurt by the crisis. Household consumption in China accounts for a mere 30 percent of GDP, down from more than 50 percent in the 1980s.

\section{Rebalancing growth to develop the domestic market}

Thus, officially the stimulus plan seeks to ensure the stability and growth of the domestic market by boosting demand through the rebuilding of the now tattered social safety network. The aim is to double the 2008 average rural income by 2020 through several projects, including land development. The Party plenum in October 2008, held just as the effects of the crisis began to be felt, was devoted to rural reforms, but with limited concrete developments, as the issue of property rights had yet to be settled. Quite apart from unequal development, the rural land use system is at the centre of more than 65 percent of mass incidents of unrest. ${ }^{(27)} \mathrm{At}$ the same time, the system helps enrich local authorities and serves the Party's short-term goal of consolidating its network by allowing local cadres to benefit.

Moreover, the declared ambition for balanced growth is hardly new and confronts a system in which desire for reform is limited by fear of instability. Thus, in the wake of the 1997 Asian financial crisis, the Central Committee working group on the economy had decided on the need to refocus China's development model on more sustained growth right from December 1998. But then as now, short-term imperatives prevailed over more complex long-term strategies in the interests of limiting risk for the regime. ${ }^{(28)}$

\section{Stimulating credit and consumption}

As part of the economic stimulus, the central bank also put out directives to encourage credit for small and mediumsized enterprises, traditional recipients of state support that account for 80 percent of the job market. ${ }^{(29)}$ Measures were also adopted to ease credit to encourage the creation of individual enterprises in rural areas.

In January 2009, however, 90 percent of the credit disbursed by banks as part of the stimulus plan went to state firms, and of the ten industrial projects identified as priority cases, eight involved state firms. ${ }^{(30)}$ The same situation prevailed in the disbursement of \$54 billion for innovation and restructuring presented to the NPC as part of the stimulus package. ${ }^{(31)}$ Direct aid was put in place to artificially and quickly stimulate the domestic market. In the countryside, subsidies of up to 13 percent of product price were extended for the purchase of consumer goods such as televisions, refrigerators, mobile phones, washing machines, and automobiles, whereas such aid had traditionally gone to farm produce. ${ }^{(32)}$ Vouchers of 22 yuan in cities and 14 yuan in the countryside were also distributed with a view to boosting consumption.

\section{Limits of the stimulus plan}

Right from early 2009, the Chinese authorities have claimed positive results from the stimulus plan, but many doubts remain regarding its reach and long-term effectiveness. Apart from the amount, the issue of financing has been raised, and contradicting official statements, some analysts say the real level of central government debt has already reached 50 percent of GDP. The central authorities' share would in reality be limited to a quarter of the projected $\$ 586$ billion, at least half of the remainder coming from local authorities and banks. ${ }^{(33)}$ In the first quarter of 2009, the amount of new credit allocated increased rapidly, but the actual total is difficult to calculate. The aim was to boost production and overall growth, but that could prove shortsighted should internal and external consumption fail to regain dynamism. By mid-2009, hopes of a rapid recovery as well as the veracity of statistics appeared open to question. Also at issue was the choice of infrastructure projects funded by the stimulus plan. Thanks to a decision-making system that is difficult to overhaul in the short term, the authorities are heavily reliant on major state firms - who are the primary recipients of credit, notably through the Party's links at all levels - as well as on public enterprises and banks.

Other major risks include corruption, despite frequent calls by the central authorities for strict control over the use of funds, and the financing of economically unviable state firms at the provincial or municipal levels. ${ }^{(34)}$

27. Nanfang zhoumou cited in Joseph Fewsmith, "Tackling the Land Issue," China Leadership Monitor, $\mathrm{n}^{\circ} 27$.

28. David Kelly, "China Facing the Inevitable," art. cit.

29. Washington Post, 6 March 2009.

30. "Private Business Sidelined by China's Stimulus," The Economic Observer Online, 16 March 2009.

31. Victor Shih, "Beijing's Legless Stimulus," Wall Street Journal Asia, 4 April 2009.

32. Xinhua, 1 February 2009.

33. Victor Shih, "Beijing's Legless Stimulus," op. cit.

34. A case in point is Chongqing, which, given municipal Party secretary Bo Xilai's national stature, requested $\$ 20$ billion out of the $\$ 100$ billion announced for post-earthquake reconstruction in Sichuan, essentially for bailing out state enterprises. See Wu Hongying, quoted in Victor Shih, Elite Chinese Politics and Political Economy, http://chinesepolitics.blogspot.com/2008_11_01_archive.html (22 July 2009). 
If the stimulus plan does produce results adequate to forestall a major fall in the 2009 growth rate, the positive effect on jobs and domestic consumption would seem to be less certain.

\section{Short-term enticement and support to boost exports}

Facing a rapid fall in exports, Chinese authorities took steps right from late 2008 to encourage manufacturing and exports in the short term. In December, Minister of Industry and Information Technology Li Yizhang said China would use all possible tariff systems to facilitate exports in labour-intensive sectors. ${ }^{(35)}$ Ten key sectors were chosen: textiles, light industry, electronics, automobiles - sales of which had fallen by 14 percent in January 2009 only to rebound by 25 percent in March - shipbuilding, machine tools, steel, non-ferrous metals, and petrochemicals. ${ }^{(36)}$ Commerce Minister Chen Deming told the NPC that a number of steps would be taken to bolster exports through taxes and development of credit. $^{(37)}$

\section{The authorities face limits to the Chinese model}

The crisis has heightened both the expectations of and the lack of confidence in the authorities and the system's functioning. A weakened leadership may be tempted to take recourse in nationalism or fall back on ideology to deal with rising dissent. There is a real risk of endemic social unrest, which could proliferate and become less controllable if the crisis persists, and of fractures along regional and provincial lines. ${ }^{(38)}$

\section{Development of control capacity}

Aware of the risk of internal disorder, the leadership has sought to adopt a strategy aimed at defusing discontent and keeping order. In January 2009, the Party's Central Commission for Discipline Inspection held a plenary session that called for better conduct on the part of cadres and urged special attention to people's needs and suggestions for resolving social problems. ${ }^{(39)}$ By mid-2009, high-ranking officials in Guangdong and Tianjin had been arrested for corruption.

At the same time, public security authorities were mobilised, and the People's Armed Police, the poor cousin of the powerful People's Liberation Army, received a 32.6 percent budget increase in 2009, taking the outlay to 116 billion yuan. ${ }^{(40)}$

Even so, the gathering uncertainties stoke deeply held fears of "internal disorder" and can unleash nationalist tendencies that have a bearing on Beijing's external strategy, even if the authorities prefer to limit the use of such tendencies for domestic purposes.

\section{Nationalist temptations}

A book published in the spring of 2009 expounded on the theme of China's humiliation by Western powers in blocking its rise, and on the need for Beijing to impose its own norms on the international arena. Quite apart from the publicity that greeted the book, China's readiness to defend its interests and challenge the international order dominated by the "West" has been evident in the demands it has made on issues such as finance during the G20 Summit or on the environment in the run-up to the Copenhagen climate conference in December 2009. ${ }^{(4)}$

On Internet websites, some form of implicit or passive encouragement is being given to nationalistic blogs, despite the difficulty of keeping the rhetoric under control. There is a genuine tendency to divert popular discontent, especially that of some educated urban youths towards foreign scapegoats, as witnessed, for instance, during the rupture with Paris until at least mid-2009. Thus "public opinion" has become a useful tool - perhaps manipulated - for the Chinese authorities in their dealings with the rest of the world.

More worryingly, this temptation toward nationalism can take the form of military gestures with serious consequences. This has been the case with Japan in the East China Sea, where clashes occurred in the autumn of 2008 despite cooperation accords signed in June the same year. It has also been evident in the South China Sea, with several naval incidents with the United States, and the tone raised against littoral states such as the Philippines despite agreements signed with the Association of Southeast Asian Nations. This strategy weighs against the perception of China as a responsible actor on the international scene. ${ }^{(42)}$

Finally, nationalism has reared its head in economic relations - though China is hardly alone in this respect - thus

35. Xinhua, 19 December 2009.

36. "Chinese Manufacturers on the Brink of Failure," www.caijing.com, 3 February 2009.

37. Xinhua, 10 March 2009

38. Peh Shing Huei, "China Signals Shift in Focus, Eyes 8 percent Growth," art. cit.

39. Xinhua, 13 January 2009.

40. In Peh Shinghuei, op. cit., and Andrew Jacobs, International Herald Tribune, 23 February 2009.

41. Huang Jisu, Song Xiaojun, Wang Xiaodong, Liu Yang, Song Qiang, Zhongguo bu gaoxing, (China Is Unhappy), Nanjing, Jiangsu People's Publishing House, 2009.

42. Similarly, in March 2009 China objected to an Asian Development Bank funding project for India, as it covered part of territory that Beijing disputes. 
undermining the hopes raised by Beijing's theoretical integration into the global system through WTO accession. ${ }^{(4)}$ In time, the economic crisis could also have a bearing on China's action on the international scene, even if the crisis provides an opportunity for bolstering Beijing's influence in strategic sectors such as energy and raw materials. This may especially prove true in China's role in Africa and its stand on environment.

\section{"Beijing consensus" less attractive for Africa?}

In Africa, where Beijing stands in clear opposition to the Western model by advancing the "efficiency" of its action as against "interference" from the West, the Chinese model could yet be questioned should the crisis persist. The fall in China's growth rate has already affected the price of raw materials and oil (which to a great extent had fuelled the continent's growth) in recent years on the order of 5 percent.

The development aid China has been granting African countries for a number of years could be reconsidered if growth continues to slow. Despite repeated official statements that China would not abandon Africa, domestic public hostility expressed freely via the Internet could weigh on the authorities' decisions.

In the case of Guinea, China is now hesitating to invest in infrastructural development, officially due to the risk of political instability, but also because the collapse of raw material prices has weakened Chinese firms' interest in African investments. Similarly, an agreed \$9 billion in aid to the Democratic Republic of Congo, meant for infrastructural development facilitating access to mineral reserves, now seems threatened. ${ }^{(44)}$

\section{The environment issue}

Similar questions linked to a reduction of resources and an overhaul of priorities weigh on the issues of environment and sustainable development. While Beijing created a "super ministry" of environment under pressure from abroad in 2008, resources have not been forthcoming, and questions have arisen over the authorities' ability to impose a long-term strategy on all levels of decision-making.

Thus, the economic crisis might have provided welcome justification to the authorities, who have stepped up warnings in the run-up to the Copenhagen summit of the impossibility for China to impose greater curbs at a time of crisis. Within China, new technologies and renewable energy could open up opportunities, with some analysts noting that the domestic automobile industry could turn out electric vehicles "within ten years" and thus assert Chinese might in the face of older industrial powers. ${ }^{(4)}$

On the other hand, however, social pressures and the risks of unemployment do not favour a real challenge to the supremacy of polluting industries and coal. The support proposed by the authorities gives prominence to the most energy-hungry and polluting industries. In the current Chinese system, the pressure of ensuring growth and the fear of unemployment, especially at the local level, can only militate against any measure that could lead to a slowdown - however beneficial to the environment - and act as a break on exports through the imposition of new duties or rules or the shuttering of polluting industries. ${ }^{(46)}$

\section{Conclusion}

According to a statement from Beijing, the crisis might give China an opportunity to impose the reforms widely deemed necessary to consolidate the regime and defend the Chinese model. Similarly in the international arena, some analysts in Beijing say the crisis could lead to a major shift of the global balance of power in Beijing's favour.

At the same time, the Chinese economy's heavy reliance on foreign trade and globalisation has been exposed as the Achilles' heel of a leadership that is at pains to impose itself and the measures it advocates to deal with the situation. Further, the question remains whether the crisis will make Beijing more receptive to calls from abroad while the maintenance of stability, growth, and domestic order remain the regime's priorities, or whether it perceives threats to its survival and chooses to "export" its way out, both economically and politically, through recourse to nationalism and denunciation of foreign enemies as a means of controlling "internal disorder." These doubtless are the two temptations Beijing's top leadership faces today.

\section{- Translated by N. Jayaram}

43. Renmin Ribao, 19 March 2009

44. Lydia Polgreen, "As Chinese Investment in Africa Drops, Hope Sinks," The New York Times, 26 March 2009.

45. Interview with Ding Yifan, March 2009

46. Russell Leigh Moses, "What Beijing Growth Plan Means," Project Syndicate, 25 March 2009 